\title{
STUDIES ON ALCOHOL DIURESIS. I. THE EFFECT OF ETHYL ALCOHOL INGESTION ON WATER, ELECTROLYTE AND ACID-BASE METABOLISM 1,2
}

\author{
By MILTON E. RUBINI,3 CHARLES R. KLEEMAN, AND EZRA LAMDIN * \\ (From the Department of Internal Medicine, Yale University School of Medicine, \\ New Haven, Conn.)
}

(Submitted for publication September 7, 1954; accepted November 24, 1954)

The diuresis following the ingestion of alcohol has been compared with the increased urine flow secondary to water ingestion (1). Van Dyke and Ames (2) demonstrated that the injection of small amounts of alcohol ( 12 to $50 \mathrm{mg}$. per $\mathrm{Kg}$.) into the carotid artery of normal unanesthetized dogs evoked a prompt diuresis without any detectable alcohol in the systemic venous blood. No increased diuresis occurred in dogs with diabetes insipidus following intracarotid injection. As alcohol has no direct effect on exogenous antidiuretic hormone $(\mathrm{ADH})$, or on the responsiveness of the renal tubules to this hormone (3), most investigators agree that "alcohol diuresis" is probably due to suppression of the release of $\mathrm{ADH}$. Little attempt has been made, however, to correlate simultaneously its effect on water excretion with electrolyte excretion, acid-base changes, and alterations in blood volume.

The study was divided into three parts: Part I. Effect of alcohol ingestion on water, electrolyte, and acid-base metabolism in semi-recumbent hydrated normal subjects; Part II. Evaluation of the inhibition of ADH secretion by alcohol, in normal subjects in whom acute changes of extracellular fluid tonicity and "effective circulating blood volume" were induced; Part III. Evaluation in pathologic states in which abnormal function of the neurohypophyseal system had been demonstrated or postulated.

\section{MATERIALS AND METHODS}

The subjects were three normal males, on unrestricted diets, ages 29 to 30 . From 7:00 to 7:30 A.M. on the

1 Supported in part by a Grant from the U. S. Public Health Service.

2 Presented in abstract form at the meeting of the American Society for Clinical Investigation, Atlantic City, May 2-5, 1954.

3 Major, MC., USA.

Postdoctorate Research Fellow of the U. S. Public Health Service. morning of each experiment the subject ate a light breakfast, including 400 to $800 \mathrm{cc}$. of fluid. At 8:30 the subject emptied his bladder, was weighed, and assumed the semi-recumbent position, standing to void at onehalf to hourly intervals. Each experiment lasted from three to five hours. Fifty cc. of $\mathrm{H}_{2} \mathrm{O}$ were ingested hourly to cover approximately the insensible water losses. Venous blood was drawn under oil, without stasis, shortly after reclining or just prior to alcohol ingestion and at two-hour intervals thereafter. When alcohol was imbibed, additional samples were taken every half-hour for the determination of alcohol. In all experiments an indwelling Cournand needle was inserted to avoid the trauma of multiple vena punctures.

Two or three control experiments and two alcohol experiments were done on each subject. One hundred and twenty cc. of 100 proof Kentucky bourbon (approximately 48 grams of ethyl alcohol) were imbibed over a five to ten-minute period one and a half hours after reclining. In the control studies $120 \mathrm{cc}$. of water were ingested.

Sodium, potassium, chloride, and $\mathrm{pH}$ of serum, and sodium, potassium, chloride, $\mathrm{pH}$, ammonia, and titratable acids of urine were measured by methods that have been described in previous reports from this laboratory $(4,5)$. Creatinine of serum and urine was determined by a modification of the method of Hare (6), blood alcohol by the method of Lester and Greenberg (7). In some experiments the osmolarity of serum was estimated from the depression of the freezing point measured by means of a Fiske osmometer.

\section{Calculations}

a) Changes in plasma volume were calculated by the formula :

$$
\frac{\mathrm{PV}_{2}}{\mathrm{PV}_{1}}=\frac{(1-\text { Hct.2 }}{(1-\text { Hct. })} \times \frac{\mathrm{Hb} .1}{\mathrm{Hb.2}} \times 100
$$

PV. = plasma volume, Hct. $=$ hematocrit (vol. per 100 cc.)

$\mathrm{Hb} .=$ hemoglobin (grams per $100 \mathrm{cc}$ )

b) Urine volume was divided into two moieties as described by Wesson (9). One is represented by the volume of water required to make the urine solutes isosmotic with the plasma. This is designated osmolar clearance ( $\left.\mathrm{C}_{0 . \mathrm{m}}\right)$, and is represented by the equation:

$$
\mathrm{C}_{\text {osm }}=\frac{\mathrm{U}_{\text {osm }} \mathrm{V}}{\mathrm{P}_{\text {oem }}}
$$

$\mathrm{V}=$ urine volume per $\mathrm{min}$. $\mathrm{U}_{\mathrm{sem}}=$ urine osmolarity in 
mOsm. per $\mathrm{Kg}$. urine $\mathrm{H}_{2} \mathrm{O}$. $P_{\text {osm }}=$ plasma osmolarity in mOsm. per $\mathrm{Kg}$. plasma $\mathrm{H}_{2} \mathrm{O}$.

The other moiety represents the net excess or deficit of water beyond the osmolar clearance, and is designated free water clearance $\left(\mathrm{C}_{2} \mathrm{O}\right)$. It is represented by the formula $\mathrm{C}_{\mathrm{H}_{2} \mathrm{O}}=\mathrm{V}-\mathrm{C}_{\text {osm. }}$. The urine volume, $\mathrm{V}=$ Cosm $+\mathrm{C}_{\mathrm{H}_{2} \mathrm{O}}$. Free water clearance is positive when the urine is diluted below the isosmotic state by the contribution of water virtually free of solute, and negative when the urine is concentrated by the reabsorption or removal of water free of solute as in antidiuresis. This definition of free water clearance should not be construed as indicating the exact mechanism by which the urine is concentrated or diluted.

Reference should be made to the contribution of ethyl alcohol to the osmolarity of plasma and urine. At the concentrations of alcohol found in the present study the depression of the freezing point was proportional to the mole fraction of alcohol in these fluids, i.e., one millimol of alcohol was equivalent to one milliosmol. Alcohol is diffusible throughout the total body water, and its concentration in serum water and urine is essentially the same. It appears to move freely in both directions across the cells of the renal tubule independent of the flow of urine and the excretion of other solutes (10) and to have no affect on the osmotic distribution of water. For this reason it seemed appropriate to subtract the osmolar contribution of alcohol from the total osmolarity of serum and urine prior to calculating osmolar clearance $\left(\mathrm{C}_{\text {osm }}\right)$.

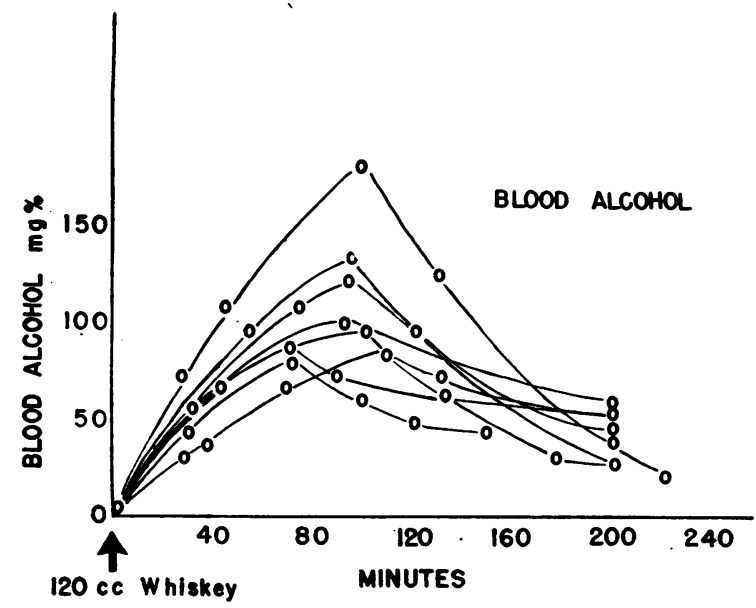

Fig. 1. The Pattern of Changes in Alcohol Levels IN THE BLOOD AFTER INGESTION

The prealcohol concentration was assumed to be zero.

RESULTS

\section{Blood alcohol (Figure 1)}

The concentration of alcohol in the blood rose progressively during the first sixty to ninety minutes after its ingestion. The mean concentration

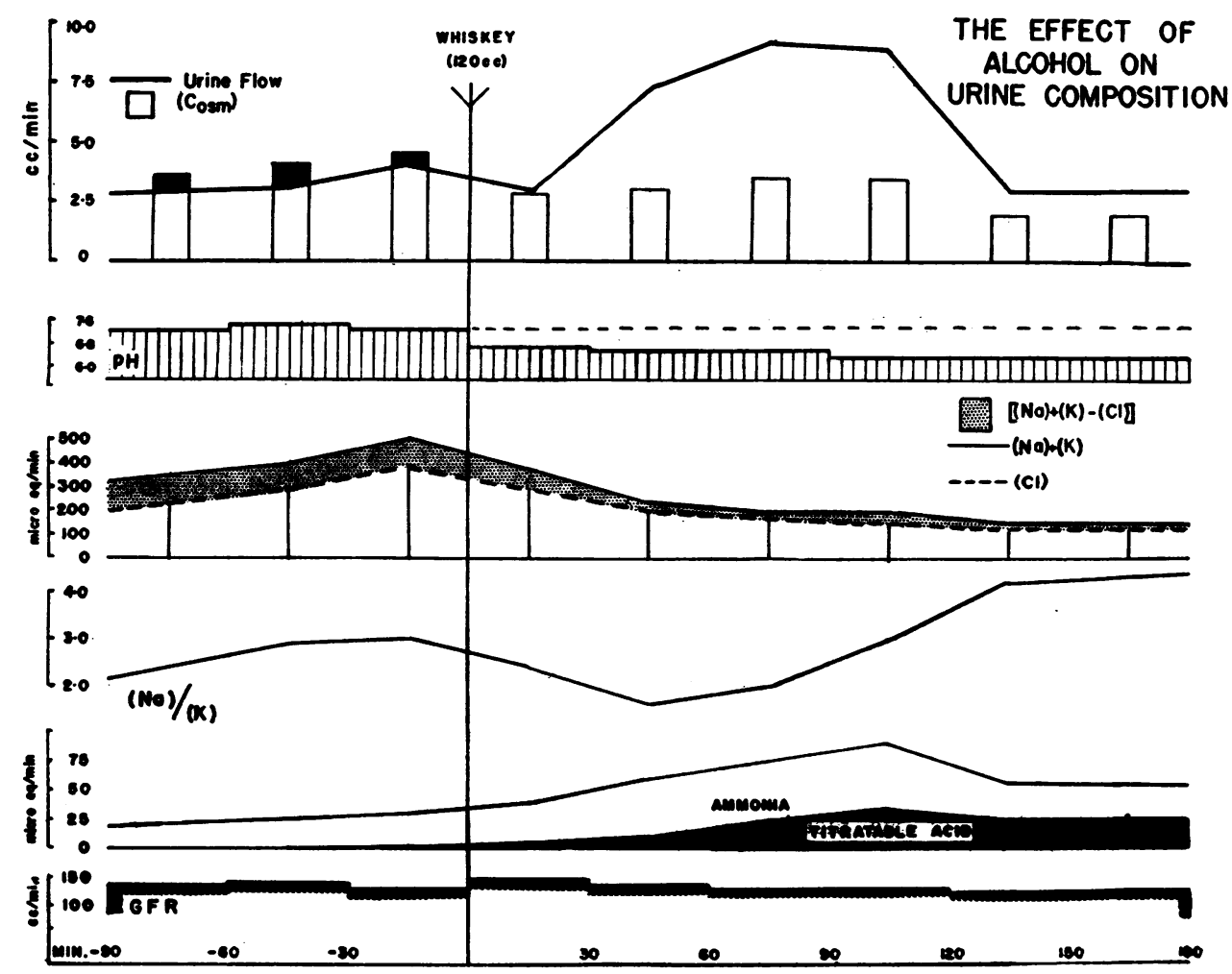

Fig. 2. This Figure Illustrates the Characteristic Changes in Urinary Composition Following the Ingestion of Alcohol 
at ninety minutes was $110 \mathrm{mg}$. per cent with a range of 60 to $180 \mathrm{mg}$. per cent. It fell gradually in a course resembling an exponential curve. Three hours after ingestion 25 to $50 \mathrm{mg}$. per cent of alcohol remained in the blood. The characteristics of the curves of the blood alcohol were similar to those noted by Haggard, Greenberg, and Carroll (10). The rise in concentration of alcohol in the blood was attended by mild inebriation.

In comparison with the control studies, two major changes occurred following the imbibition of alcohol: 1) Increased urine flow with decreased solute excretion; and 2) extracellular acidosis with increased excretion of titratable acid and ammonia. The typical changes in urine composition are illustrated in Figure 2.

In all studies (Tables I and II) only minor fluctuations in creatinine clearance occurred, and these could not be correlated with changes in urine flow or solute excretion. The failure of alcohol in doses comparable to those used in the present study to alter glomerular filtration rate has been previously demonstrated (3).

\section{Urine flow (Table I and II)}

In the control experiment, under the conditions of the present study, diurnal variation and the assumption of the semi-reclining position led to two to threefold rises in urine flow. In contrast, in five of the alcohol studies urine flow increased three to tenfold. In one experiment, R.9/17, urine flow did not rise after alcohol ingestion. This subject's rate of excretion of sodium was much lower than any other in the present study. This is consistent with the observations of Rosenbaum and his co-workers (11) in which urine flow after water loading was correlated with the renal excretion of solutes.

\section{CHANGE IN THE RATE OF \\ EXCRETION OF SODIUM}

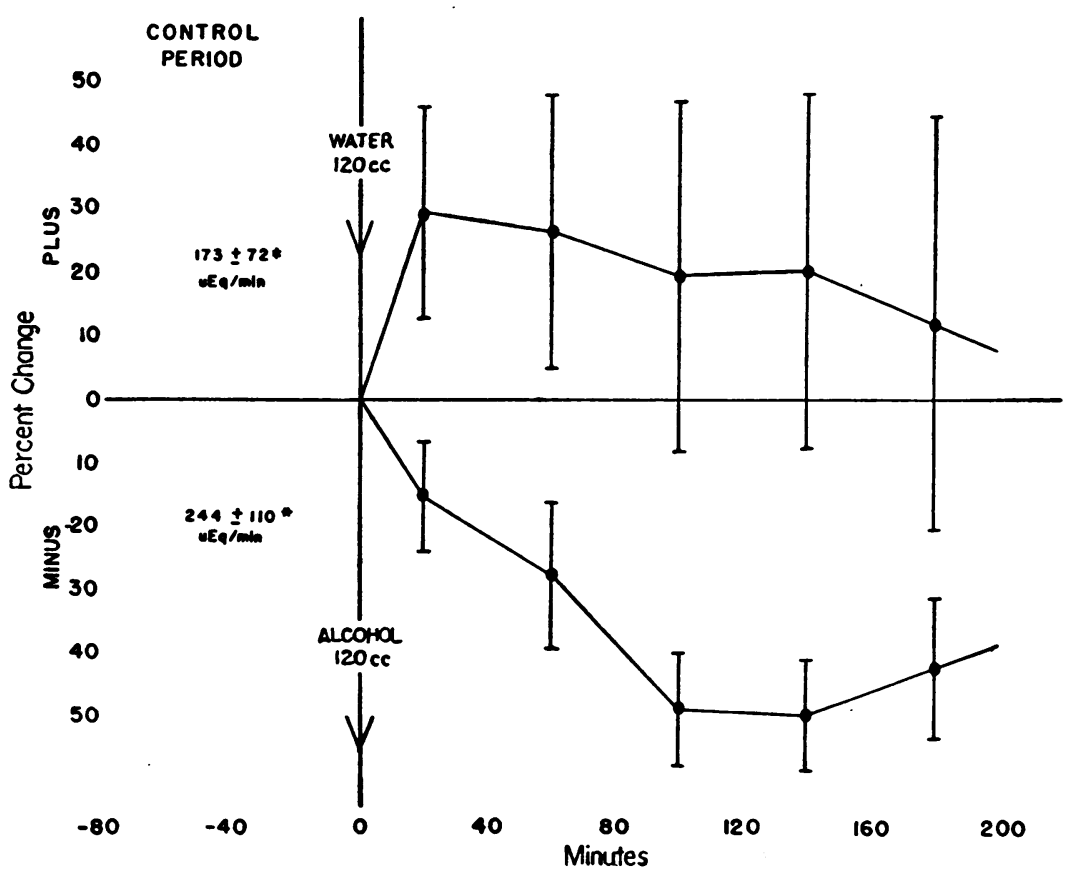

Fig. 3. The Effect of Administration of Alcohol on the Excretion of Sobrux

The vertical brackets at each point represent twice the standard error of mean. Note that there is no overlap between the control subjects and those receiving alcohol.

* The mean rate of excretion of sodium with $2 \times$ the standard deviation during the initial period. 


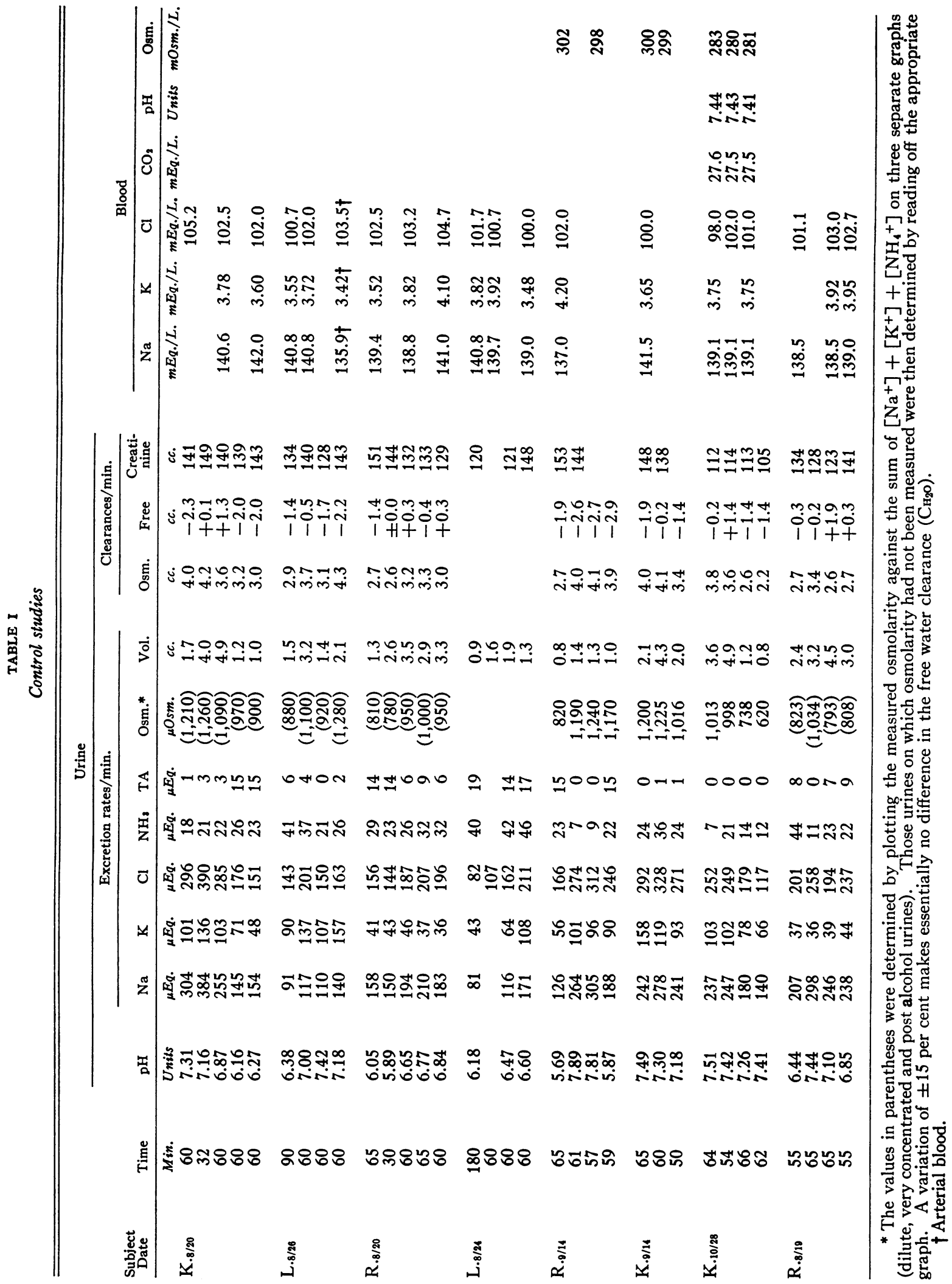


EFFECT OF ETHANOL ON WATER AND MINERAL METABOLISM

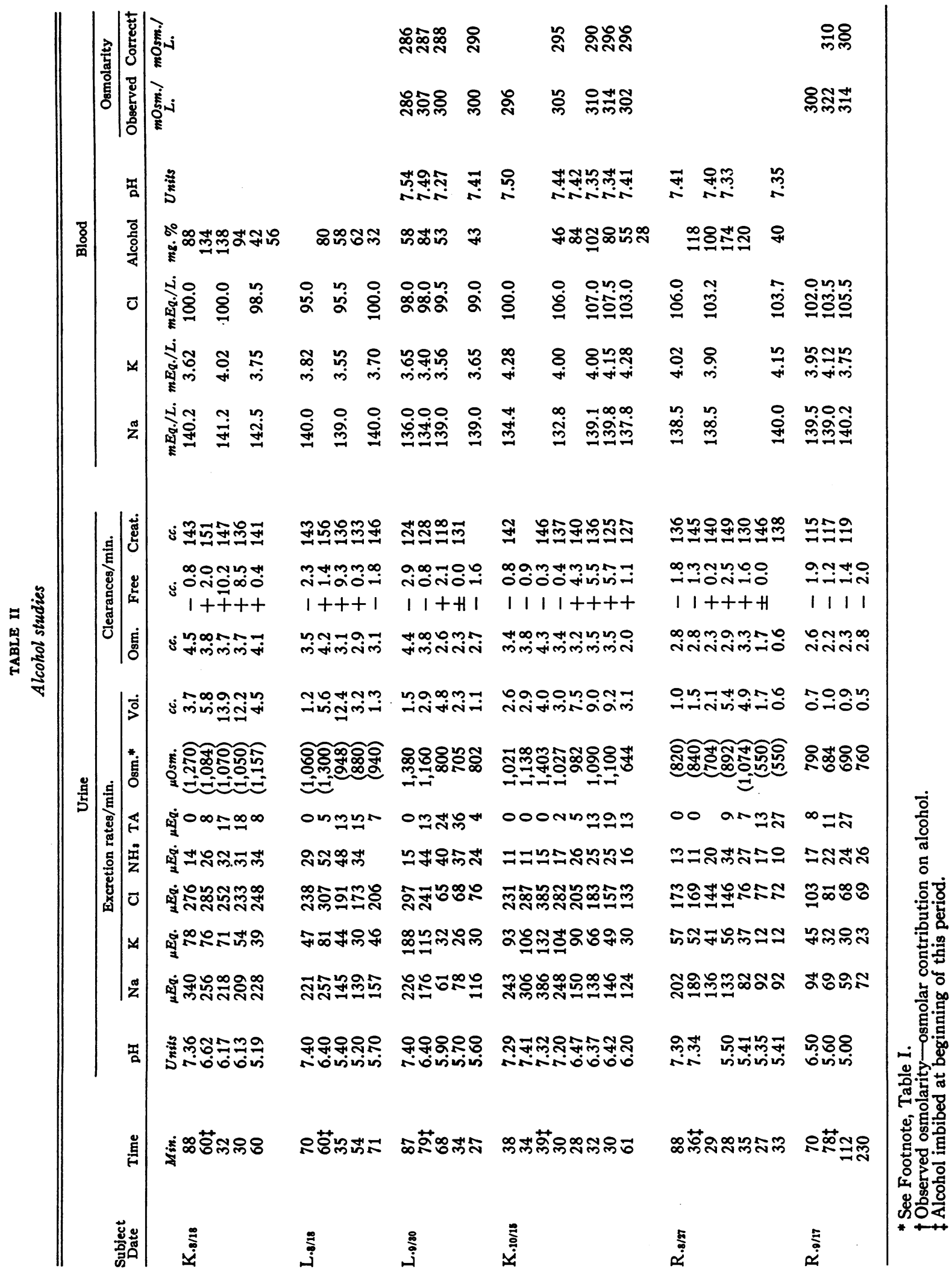




\section{Solute excretion (Tables I, II, and Figure 3)}

In Figure 3 the differences in the excretion of sodium between the control and alcohol experiments are plotted as a per cent change from the control period. The pattern of the excretion of sodium in the control subjects reflected the effect of the semi-recumbent position (12) and diurnal variation (13). It is apparent that a prompt fall in the excretion of sodium followed the ingestion of alcohol. This fall preceded the rise in urinary flow in most instances and persisted after the flow returned to prealcohol rates. Although the rates of excretion of potassium and chloride (Tables I, II) are not plotted, they also fell promptly after imbibition of alcohol. The early fall in the (Na)/ (K) ratio after alcohol (Figure 2) appeared to indicate a greater effect on the excretion of sodium. In the control subjects sodium + potassium - chloride initially rose, with a subsequent fall. In the subjects receiving alcohol, sodium + potassium - chloride fell progressively (Tables I, II, and Figure 2). A temporally related rise in ammonia and titratable acid excretion (Tables I, II, and Figure 2) accounted for only a small portion of the diminished excretion of sodium and potassium. The percentage fall in solute excretion of Subject R.9/17, who had no diuresis following alcohol ingestion, was as great as that in the other alcohol experiments. This response is similar to that seen in one subject reported by Eggleton and Smith (14) who, in spite of a minimal diuresis following the ingestion of alcohol, had a definite fall in chloride excretion. The reversal of the morning diurnal pattern of the electrolyte excretion (13) is indicative of the "potency" of the physiologic stimulus of alcohol.

\section{Partition of water excretion}

In Figure 4 are plotted the mean changes in free water clearance $\left(\mathrm{C}_{2} \mathrm{O}\right)$. In the control group a slight rise occurred in the first hour after the control period, followed by a gradual decline. The slight increase in urinary flow in the control subjects reflected a parallel rise in osmolar and

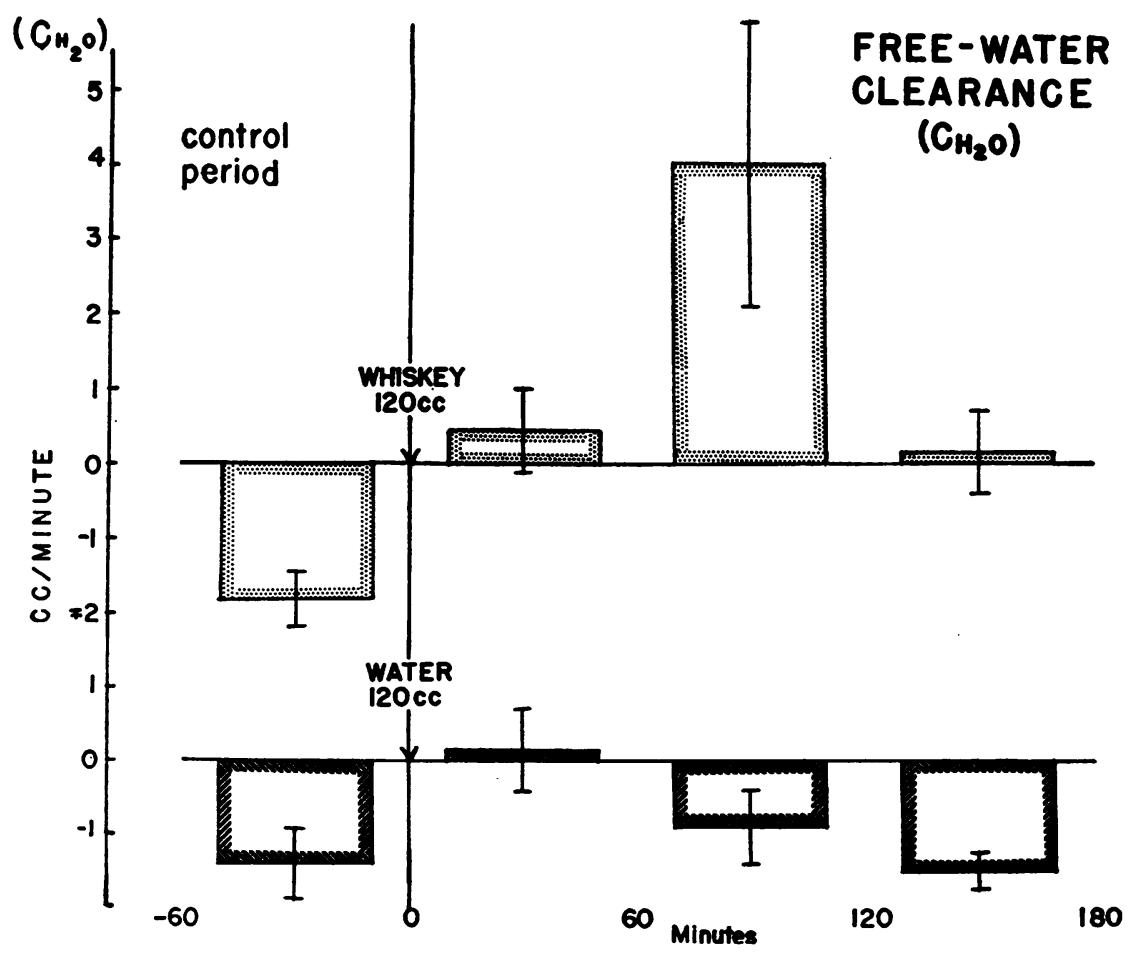

Fig. 4. A Comparison of the Effect of 120 cc. of Alcohol and Water on the Free Water Clearance ( $\mathrm{C}_{\mathrm{H}_{2} \mathrm{O}}$ )

The vertical bracket at the top of each block represents $2 \times$ the standard error or mean. 
TABLE III

A comparison of the changes in serum electrolytes and plasma volume after ingestion of $120 \mathrm{cc}$. of alcohol or water

\begin{tabular}{|c|c|c|c|c|c|}
\hline \multirow[b]{2}{*}{$\begin{array}{c}\text { Time } \\
\text { after } \\
\text { ingestion }\end{array}$} & \multirow[b]{2}{*}{ Measurement } & \multicolumn{2}{|r|}{ After alcohol } & \multicolumn{2}{|r|}{ After water } \\
\hline & & $\begin{array}{l}\text { No. of } \\
\text { obs. }\end{array}$ & $\begin{array}{l}\text { Mean change from } \\
\text { control period in } \\
\mathrm{mEq} . / \mathrm{L} \text {. with S.D. }\end{array}$ & $\begin{array}{l}\text { No. of } \\
\text { obs. }\end{array}$ & $\begin{array}{l}\text { Mean change from } \\
\text { control period in } \\
\mathrm{mEq} / \mathrm{L} \text {. with S.D. }\end{array}$ \\
\hline $1 \mathrm{hr}$. & $\begin{array}{l}\text { Sodium } \\
\text { Potassium } \\
\text { Chloride } \\
\text { \% } \Delta \text { P.V. }\end{array}$ & $\begin{array}{l}8 \\
8 \\
8 \\
4\end{array}$ & $\begin{array}{cc}1.2 & \pm 0.7 \\
-0.19 & \pm 0.22 \\
1.2 & \pm 1.0 \\
\% \Delta 4.3 & \pm 0.7\end{array}$ & $\begin{array}{l}5 \\
4 \\
6 \\
5\end{array}$ & $\begin{aligned}-0.3 & \pm 0.2 \\
0.13 & \pm 0.05 \\
0.5 & \pm 1.0 \\
\% \Delta 3.1 & \pm 1.4\end{aligned}$ \\
\hline $2 \mathrm{hr}$. & $\begin{array}{l}\text { Sodium } \\
\text { Potassium } \\
\text { Chloride } \\
\% \Delta \text { P.V. }\end{array}$ & $\begin{array}{l}8 \\
8 \\
8 \\
4\end{array}$ & $\begin{aligned} 1.6 & \pm 0.5 \\
-0.17 & \pm 0.16 \\
1.6 & \pm 0.9 \\
\% \Delta 4.3 & \pm 0.7\end{aligned}$ & $\begin{array}{l}4 \\
5 \\
6 \\
4\end{array}$ & $\begin{aligned} 0.1 & \pm 0.7 \\
-0.01 & \pm 0.16 \\
0.6 & \pm 1.1 \\
\% \Delta-0.1 & \pm 2.7^{*}\end{aligned}$ \\
\hline
\end{tabular}

* In view of the variability in repeated determinations of hemoglobin and hematocrit this 2 -hour difference was not considered significant.

free water clearance. In the first thirty to sixty minutes after imbibing alcohol, the rise in free water clearance was associated with a fall in osmolar clearance. The contrast between the two groups was most marked in the period 60 to 120 minutes after alcohol. While the $\mathrm{CH}_{2} \mathrm{O}$ was declining in the control studies, a striking further increase occurred in the five experiments in which a diuresis was seen after alcohol ingestion. The free water clearance $\left(\mathrm{C}_{\mathrm{H}_{2}} \mathrm{O}\right)$ accounted for 60 to 80 per cent of the total urine flow. Thus the diuresis following alcohol ingestion was characterized by a decrease in osmolar and an increase in free water clearance. Even in study R.9/17 (Table II), with no obvious diuresis after alcohol, the 30 per cent fall in solute excretion with a 40 per cent rise in free water clearance was consistent with the effect of alcohol in the other studies. The maximum free water clearance coincided with the peak of the diuresis after alcohol.

\section{Acid-base changes}

In the present studies a fall in the $\mathrm{pH}$ of the blood of $0.13 \pm .03 \mathrm{pH}$ units occurred during the first hour after alcohol imbibition. The peak of this acidosis coincided approximately with the greatest concentration of alcohol in the blood, and returned toward normal at the end of the experiments. Bicarbonate of the serum, determined in subsequent studies (15), also fell, and in several instances the calculated $\mathrm{pCO}_{2}$ (16) rose above the normal mean of $40 \mathrm{~mm}$. $\mathrm{Hg}$. This suggests that the acidosis secondary to alcohol administration is a combined metabolic and respiratory aci- dosis. Seligson and his co-workers (17) and Nicholson and Taylor (18) have described a moderate metabolic acidosis following the ingestion of alcohol.

\section{Blood volume changes (Table III)}

In the control studies calculated plasma volume rose slightly after the assumption of the semi-recumbent position. It did not increase significantly after imbibition of alcohol. In one alcohol experiment the slight increase determined by the $\mathrm{Hb}$.-Hct. method was confirmed by the radioactive chromium technique (19).

\section{DISCUSSION}

In the present study water diuresis is best characterized as a rise in free water clearance. If the assumption is made that in the normal kidney this moiety of water can only increase when there is a decrease in circulating $\mathrm{ADH}$ or a decreased responsiveness of the renal tubules to $\mathrm{ADH}$, alcohol must exert its effect through one or both of these mechanisms. Strauss, Rosenbaum, and Nelson (3) and Eggleton (1) have shown that following the administration of alcohol the renal tubule is capable of responding to exogenous antidiuretic hormone. The conclusion that alcohol acts directly on the supraoptico hypophyseal system is convincing. Acetyl choline and nicotine are strong chemical stimulators of $\mathrm{ADH}$ release. Eggleton (1) demonstrated that nicotine administered prior to ingestion of alcohol could prevent the expected diuresis. Van Dyke and Ames (2) 
were able to block the effect of acetyl choline by the prior administration of alcohol. Finally, the ability to produce a characteristic water diuresis by the intracarotid injection of relatively minute quantities of ethyl alcohol (2) would appear to localize conclusively its site of action. ${ }^{5}$

The peak of the diuresis or free water clearance 60 to 90 minutes after alcohol ingestion coincided with the peak level of alcohol in the blood (Figure 1). The onset of the alcohol diuresis and the characteristics of the diuretic curve were shown by Eggleton (1) to be very similar to those following a load of water. The time lag of sixty to ninety minutes probably is associated with the inactivation of circulating ADH. This lag implies that alcohol must have blocked the release of $\mathrm{ADH}$ during the early period of its rise in the blood.

As pointed out by van Dyke and Ames (2) and Eggleton (1) the maintenance of elevated levels of alcohol in the blood does not sustain the diuresis. This is not due to the development of dehydration, since a second dose of alcohol taken after the effects of the first have worn off will lead to a second diuresis, though of lesser magnitude than the first.

A definitive mechanism by which alcohol decreases the excretion of sodium, potassium, and chloride could not be derived from the present study. Alcohol did not cause consistent changes in glomerular filtration rate or in the level of these electrolytes in the serum (Table III). Although the acidosis, with the associated rise in titratable acid and ammonia, would lead to some reabsorption of sodium by the exchange mechanism, quantitatively it could account for, at most, 20 per cent of the retained sodium. A slight degree of dehydration is induced by the loss of water in excess of sodium following alcohol ingestion. Since, however, the initial fall of sodium excretion preceded the rise of free water clearance, the "dehydration reaction" (20) cannot be implicated. Stimulation of the adrenals and inhibition of the posterior pituitary are unlikely causes of the sodium retention as the decrease in the excretion of sodium after alcohol occurred in a patient with

\footnotetext{
5 The experiments of van Dyke and Ames (2) were performed on dogs and, while conclusive for this species, their extrapolation to humans should be done with caution.
}

Addison's disease on a constant intake of DOCA, ${ }^{\circ}$ and in a case of diabetes inspidus receiving no exogenous $\mathrm{ADH}$ (15). Whether this enhanced reabsorption was due to a direct effect of alcohol on the renal tubules is not known. Eggleton and Smith (14) also noted falls in the excretion of chloride following alcohol. Strauss, Rosenbaum, and Nelson (3) failed to observe greater decreases in solute excretion after alcohol than seen in their control group. Their studies were performed in the afternoon, with the subjects in the sitting position; both of these are important differences from the present study. Although the ingestion of alcohol did not cause significant changes in total blood volume (Table III), the peripheral vasodilation following its ingestion must have caused a redistribution of the blood. (It is possible that the latter, by a presently unknown mechanism, was the effective stimulus for the increased tubular reabsorption of sodium and chloride.)

The cause of the potassium retention is also unexplained. However, acidosis per se (21) and the intermediary metabolism of the alcohol may. be important contributors.

The acidosis, the changes in electrolyte excretion, and the alterations in blood volume and renal hemodynamics cannot be related causally to the diuresis or rise of free water clearance following alcohol ingestion.

\section{SUMMARY AND CONCLUSIONS}

The acute effects of alcohol ingestion (120 cc. whiskey) on water and electrolyte metabolism were studied in normal semi-recumbent males during the morning hours.

Alcohol caused a marked rise in urinary flow and free water clearance $\left(\mathrm{C}_{\mathrm{H}_{2} \mathrm{O}}\right)$ as well as consistent falls in the excretion of sodium, chloride, and potassium. Although no definite cause for the fall in solute excretion was discerned it is suggested that a redistribution of blood volume may have been the effective stimulus.

The acidosis, the changes in electrolyte excretion, and the alterations in blood volume and renal hemodynamics could not be causally related to the diuresis or rise of $\mathrm{CH}_{2} \mathrm{O}$ after alcohol.

- Administration of ACTH to this patient induced no fall in circulating eosinophils or rise in 17-ketosteroid excretion. 
The findings in the present study are consistent with the hypotheses that alcohol inhibits the supraoptico hypophyseal system.

\section{REFERENCES}

1. Eggleton, M. G., The diuretic action of alcohol in man. J. Physiol., 1942, 101, 172.

2. van Dyke, H. B., and Ames, R. G., Alcohol diuresis. Acta endocrinol., 1951, 7, 110.

3. Strauss, M. B., Rosenbaum, J. D., and Nelson, W. P., III, The effect of alcohol on the renal excretion of water and electrolyte. J. Clin. Invest., 1950, 29, 1053.

4. Hald, P. M., The flame photometer for the measurement of sodium and potassium in biological materials. J. Biol. Chem., 1947, 167, 499.

5. Elkinton, J. R., and Taffel, M., Prolonged water deprivation in the dog. J. Clin. Invest., 1942, 21, 787.

6. Hare, R. S., Endogenous creatinine in serum and urine. Proc. Soc. Exper. Biol. \& Med., 1950, 74, 148.

7. Lester, D., and Greenberg, L. J., Personal communication.

8. Hopper, J., Jr., Winkler, A. W., and Elkinton, J. R., Simultaneous measurements of the blood volume in man and dog by means of Evans blue dye, $\mathrm{T}-1824$, and by means of carbon monoxide. II. Under abnormal conditions, including secondary shock. J. Clin. Invest., 1944, 23, 636.

9. Wesson, L. G., Jr., Electrolyte excretion studies in the dog in Methods in Medical Research. Chicago, Year Book Publishers, 1952, vol. 5, p. 175.

10. Haggard, H. W., Greenberg, L. A., and Carroll, R. P., Studies in the absorption, distribution, and elimination of alcohol. VIII. The diuresis from alcohol and its influence on the elimination of alcohol in the urine. J. Pharmacol. \& Exper. Therap., 1941, 71, 349.
11. Rosenbaum, J. D., Nelson, W. P., III, Strauss, M. B., Davis, R. K., and Rossmeisl, E. C., Variation in the diuretic response to ingested water related to the renal excretion of solutes. J. Clin. Invest., 1953, 32, 394.

12. Strauss, M. B., Davis, R. K., Rosenbaum, J. D., and Rossmeisl, E. C., "Water diuresis" produced during recumbency by the intravenous infusion of isotonic saline solution. J. Clin. Invest., 1951, 30, 862.

13. Stanbury, S. W., and Thomson, A. E., Diurnal variation in electrolyte excretion. Clin. Sc., 1951, 10, 267.

14. Eggleton, M. G., and Smith, I. G., The effect of ethyl alcohol and some other diuretics on chloride excretion in man. J. Physiol., 1946, 104, 435.

15. Kleeman, C. R., Rubini, M. E., Lamdin, E., and Epstein, F. H., Studies on alcohol diuresis. II. The evaluation of ethyl alcohol as an inhibitor of the neurohypophysis. J. Clin. Invest., 1955, 34, 448.

16. Peters, J. P., and Van Slyke, D. D., Quantitative Clinical Chemistry, Vol. II. Methods. Baltimore, Williams \& Wilkins Co., 1932.

17. Seligson, D., Waldstein, S. S., Giges, B., Meroney, W. H., and Sborov, V. M., Some metabolic effects of ethanol in humans. Clin. Research Proc., 1953, 1, 86.

18. Nicholson, W. M., and Taylor, H. M., The effect of alcohol on the water and electrolyte balance in man. J. Clin. Invest., 1938, 17, 279.

19. Sterling, K., and Grey, S. J., Determination of the circulating red cell volume in man by radioactive chromium. J. Clin. Invest., 1950, 29, 1614.

20. Peters, J. P., Water balance in health and in disease in Diseases of Metabolism, Detailed Methods of Diagnosis and Treatment, Duncan, G. G., ed., 3rd ed., Philadelphia, W. B. Saunders Co., 1952, p. 348.

21. Berliner, R. W., Tubular secretion of potassium and acid in Renal Function, Transactions of the Third Conference, ed. by S. E. Bradley, N. Y., Josiah Macy, Jr. Foundation, 1952, p. 174. 